\title{
Dolphin and Union Caribou Herd Status and Trend
}

\author{
MATHIEU DUMOND ${ }^{1,2}$ and DAVID S. LEE 3
}

(Received 17 July 2012; accepted in revised form 4 January 2013)

\begin{abstract}
The Dolphin and Union caribou herd (Rangifer tarandus groenlandicus) is of great importance for Inuit subsistence and cultural needs. This herd is somewhat particular in that it relies on the seasonal connectivity of the sea ice between Victoria Island and the mainland to undertake its fall and spring migrations to and from its wintering ground on the mainland. While the herd may have numbered in the order of 100000 animals in the past, it experienced a dramatic decline in the early 1900s and stopped its migration to the mainland. It resumed its migration only as it started to increase during the 1980s and 1990s, and in October 1997, the caribou gathered on the southern coast (prior to crossing to the mainland) were estimated to number $27948 \pm 3367$ SE. In October 2007, using the same method and covering approximately the same area as during the 1997 survey, we estimated $21753 \pm 2343$ SE caribou within our study area. The method used in 1997 and 2007 assumes that most of the herd is located within a narrow strip along the southern coast of Victoria Island, but also acknowledges that some caribou are outside that area. Therefore, we undertook a correction of both 1997 and 2007 estimates for the Dolphin and Union caribou herd based on available data from radio-tracking of female caribou. The corrected estimate for the Dolphin and Union caribou herd in 2007 was $27787 \pm 3613$ SE. Both the study area estimates and the corrected herd estimates for 1997 and 2007 indicate that the herd trend in the intervening decade was at best stable.
\end{abstract}

Key words: caribou, Rangifer, migration, population size estimate, population trends, Dolphin and Union herd, Canada, Nunavut, Northwest Territories

RÉSUMÉ. Le troupeau de caribous Dolphin et Union (Rangifer tarandus groenlandicus) revêt une grande importance pour la subsistance et la culture des Inuits. Ce troupeau a la particularité d'utiliser la banquise pour migrer en automne et au printemps entre son aire d'estivage, sur l'île Victoria, et son aire d'hivernage sur le continent. Bien que ce troupeau ait été estimé aux alentours de 100000 individus par le passé, il a connu un déclin dramatique au début du $\mathrm{XX}^{\mathrm{e}}$ siècle et interrompu sa migration vers le continent. C'est seulement dans les années 1980 et 1990 que le troupeau a commencé à augmenter et à reprendre sa migration. En octobre 1997, les caribous assemblés le long de la côte sud, avant leur traversée vers le continent, étaient estimés à $27948 \pm 3367$ ( \pm erreur type). En octobre 2007, utilisant la même méthode, nous avons estimé $21753 \pm 2343$ (ET) caribous dans à peu près la même aire d'étude qu'en 1997. La méthodologie employée en 1997 et en 2007 présume que la majorité du troupeau se regroupe dans une bande étroite le long de la côte sud de l'île Victoria, mais reconnaît aussi qu'un certain nombre de caribous se trouve en dehors de cette zone. Par conséquent, nous avons effectué une correction des estimés de 1997 et de 2007 pour obtenir un estimé du troupeau tout entier grâce aux données de télémétrie disponibles pour les caribous femelles. Cette correction nous a permis d'estimer le troupeau Dolphin et Union à $27787 \pm 3613$ (ET) caribous en 2007. Entre 1997 et 2007, tant les estimés dans l'aire d'étude que les estimés corrigés témoignent d'un troupeau au mieux stable pour la décennie concernée.

Mots clés : caribou, Rangifer, migration, estimé de taille de population, tendance de population, troupeau Dolphin et Union, Canada, Nunavut, Territoires du Nord-Ouest

Révisé pour la revue Arctic par Nicole Giguère.

\section{INTRODUCTION}

The Dolphin and Union caribou herd (Rangifer tarandus groenlandicus) is the most genetically differentiated of the barren-ground caribou (Zittlau, 2004). Local Inuit hunters distinguish it from other caribou by its phenotype, its behavior, and the taste of its meat.

This herd is distinctive in that it relies on the seasonal connectivity of the sea ice between Victoria Island and the mainland to undertake its fall and spring migrations to and from its wintering ground on the mainland (Poole et al., 2010). The herd calves and mates on the island and spends the winter on the nearby mainland.

Conservation concerns were raised by the Kitikmeot Hunters and Trappers Association in 1997 and consultation to initiate a management plan was undertaken by the government of the Northwest Territories (GNWT-RWED, 1998), but the management plan was never drafted. Also,

\footnotetext{
${ }^{1}$ Nunavut Wildlife Division, Department of Environment, Government of Nunavut, Box 377, Kugluktuk, Nunavut X0B 0E0, Canada

${ }^{2}$ Corresponding author: mdumond@gov.nu.ca

${ }^{3}$ Nunavut Tunngavik Inc., Department of Wildlife \& Environment, Suite 1002, 75 Albert Street, Ottawa, Ontario K1P 5E7, Canada

(C) The Arctic Institute of North America
} 
because of this herd's small size, its vulnerability to harvest, and the potential future impacts of natural or anthropogenic alteration of the sea ice, the Committee on the Status of Endangered Wildlife in Canada (COSEWIC) assessed these caribou as a species of special concern (COSEWIC, 2004). The herd is listed under Schedule 1, Part 4, of the Species at Risk Act in Canada (Canada Gazette, 2011), and it has been investigated by the U.S. Fish and Wildlife Service to be listed under the Endangered Species Act (Federal Register, 2011).

After a period of very low densities reported from observational studies (see Gunn, 1990) and traditional knowledge (M. Angohiatok, unpubl. data), the herd started to increase in the late 1970s to early 1980s, and it resumed its migration to the mainland during the late 1980 s and early 1990 s (Gunn and Nishi, 1998; Gunn and Fournier, 2000). Until 1997, the herd was increasing, with a conservative estimate of $27948 \pm 3367( \pm$ SE) animals in October 1997 (Nishi and Gunn, 2004), but the status and trend of this herd since that year are unknown. However, surveys conducted in 1998, 2001 , and 2005 on a small portion $(<5 \%)$ of the herd in the northwest part of Victoria Island showed a significant $(250 \%)$ increase of caribou in that area from 1998 to 2001 and then no significant trend $(p>0.05)$ between 2001 and 2005 (Nagy et al., 2006).

Subsistence harvest levels are unknown and have fluctuated mainly in relation to availability of alternative caribou herds for mainland communities. Local hunters are reporting more animals in poor physical condition or with signs of disease (Dumond et al., 2007). Moreover, local knowledge indicates an increase of predators on the Island (Dumond et al., 2007) and increasing human activity (mining and mining exploration, Distant Early Warning line sites, maritime traffic) could affect both summer and winter ranges and migratory routes (COSEWIC, 2004; Poole et al., 2010; Dumond et al., 2013). Because of the risk of negative cumulative effects on the Dolphin and Union caribou herd and its importance to communities for subsistence, the Department of Environment, Government of Nunavut, conducted an aerial survey to estimate the herd's abundance. The survey was conducted during the fall staging of caribou on the southern coast of Victoria Island. In this paper, we examine survey results and trends since previous surveys to provide an updated status of this caribou herd.

\section{STUDY AREA}

The range of the Dolphin and Union caribou herd extends to most of Victoria Island $\left(70^{\circ} 55^{\prime} \mathrm{N} ; 109^{\circ} 59^{\prime} \mathrm{W}\right)$ and to the nearby mainland (Poole et al., 2010; Nagy et al., 2011; Fig. 1). The island has a fairly low topography, with elevations rising to only $655 \mathrm{~m}$. The island has two settlements: Cambridge Bay, Nunavut, and Holman, Northwest Territories). Cambridge Bay $\left(69^{\circ} 06^{\prime} \mathrm{N} 105^{\circ} 08^{\prime} \mathrm{W}\right)$ has a low average annual precipitation $(138.8 \mathrm{~mm})$ and mean temperatures ranging from $8.4 \pm 1.6^{\circ} \mathrm{C} \mathrm{SD}$ in summer to $-33.0 \pm$

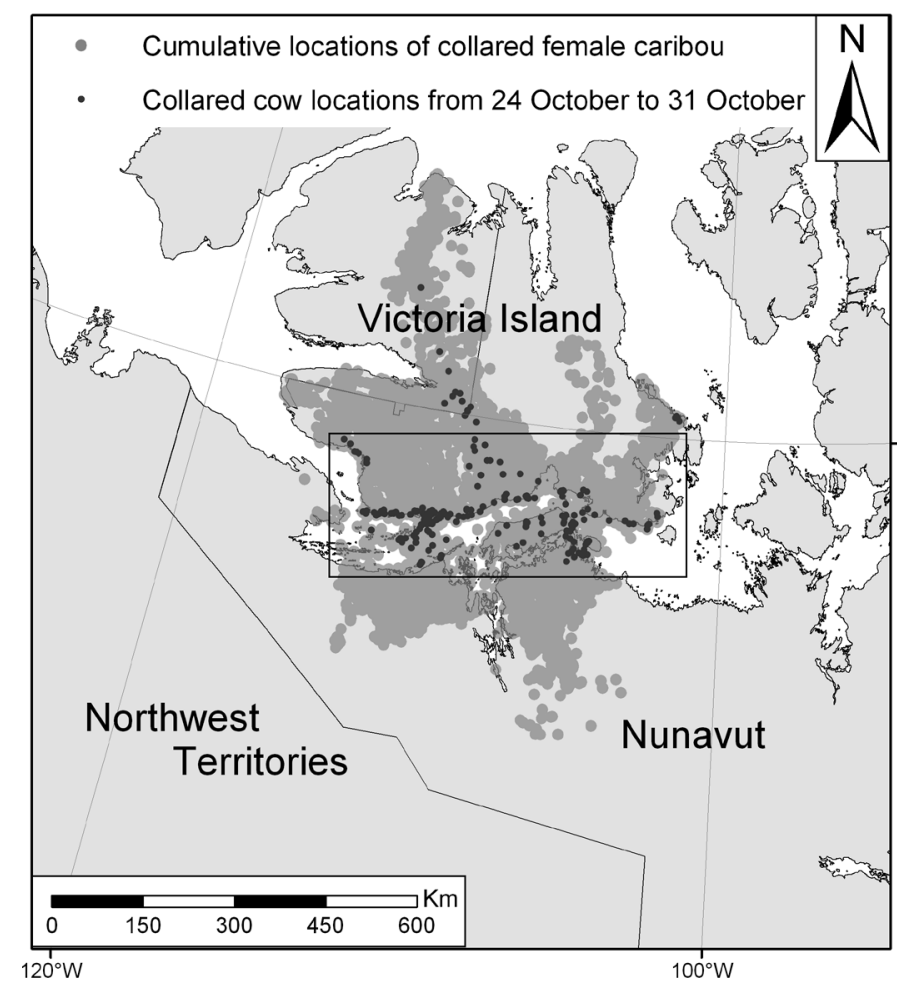

FIG. 1. General study area. Grey area shows cumulative annual distribution of Dolphin and Union caribou derived from satellite collar locations for 1999-2005. Black dots indicate cumulative locations on 24 to 31 October. Note that during our 2007 survey, caribou were unlikely to be offshore on the sea ice or on the mainland because freeze-up was late that year.

$3.2^{\circ} \mathrm{C}$ SD in winter. Snow usually covers the area from late September to early July, giving a snow-free period of only three months (Environment Canada, 2013).

The island is characterized by mesic and dry habitats dominated by prostrate shrubs with patches of wet sedgemoss tundra in the north. The southern coast supports a relatively higher biomass with vegetation similar to that on the mainland: erect dwarf-shrub tundra dominated by Carex spp. and Salix lanata, with some Oxytropis spp. (Gould et al., 2002).

Caribou share this environment with only a few mammal species: muskox (Ovibos moschatus), lemmings (Lemmus trimucronatus and Dicrostonyx spp.), Arctic hare (Lepus arcticus), Arctic fox (Alopex lagopus), red fox (Vulpes vulpes), wolf (Canis lupus), wolverines (Gulo gulo), and low densities of grizzly (Ursus arctos horribilis) and polar bears (Ursus maritimus).

Over the past 2.5 decades, later fall freeze-up of sea ice (delayed by more than three days per decade) has delayed the fall migration of the herd from the island to the mainland (Poole et al., 2010).

\section{METHODS}

The survey technique, based on the method developed by Nishi and Gunn (2004), aimed to survey most of the herd on the southern coast of Victoria Island during its fall staging 


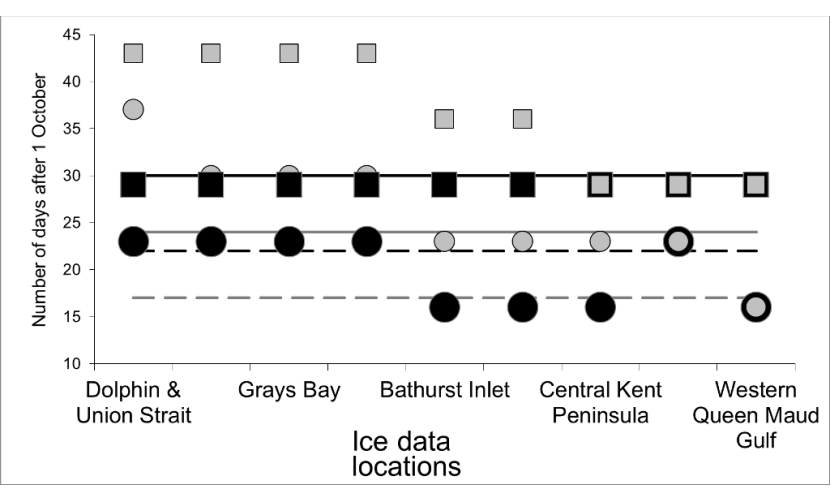

FIG. 2. Number of days from 1 October for the formation of new ice (black) and grey ice (grey) in 1997 (circles) and 2007 (squares) at various locations from west to east between Victoria Island and the Nunavut mainland (see Poole et al., 2010 for details). The lines represent the beginning and end of the surveys in 1997 (broken line) and 2007 (solid line).

period, when caribou wait for the ice to form to allow them to migrate to the wintering grounds on the mainland.

To pinpoint the start of the survey, we monitored sea ice formation patterns and caribou aggregation on the southern coast of Victoria Island using Environment Canada weather data and local observations from hunters and conservation officers. We plotted the dates for the formation of new ice $(<10 \mathrm{~cm}$ thick) and grey ice (10 to $30 \mathrm{~cm}$ thick) at various locations in 2007 (see Poole et al., 2010) and compared this plot with the 1997 ice formation pattern (Fig. 2). Like the 1997 survey, our survey was conducted one to 13 days before the formation of grey ice between Victoria Island and the mainland (Fig. 2).

We used a fixed-wing aircraft, Helio-Courier H-295, on wheel skis to conduct an aerial reconnaissance survey on 24 October 2007 (between Read Island and Cambridge Bay) and on 26 October 2007 (west and east of Cambridge Bay, Fig. 3a) and determine the distribution of the caribou along the southern coast of Victoria Island. Flight lines were oriented mainly parallel to the coast, with some inland lines to identify any gradient of distribution. All observations during the reconnaissance and the survey itself were recorded on a Global Positioning System (GPS), and the number of caribou was recorded on the observation sheet along with the date, time, and waypoint number for each observation. The aerial reconnaissance survey was used to stratify the survey according to densities observed and to ensure that the majority of the herd was gathered along the coast. The reconnaissance was done by the pilot and the principal investigator alone on 24 October and with two additional observers on 26 October 2007.

We conducted the aerial stratified strip transect survey using the same aircraft, flying at an altitude of $100 \mathrm{~m}$ above the ground and an average speed of $160 \mathrm{~km} / \mathrm{h}$ (Nishi and Gunn, 2004). In addition to the pilot (left) and the navigator (right), the survey crew consisted of a right and a left observer or only a left observer during one day (the navigator covering the right side). Observers were local residents from the community of Cambridge Bay. The first transect was randomly placed and then each sequential line was evenly spaced at a set interval within each stratum. All transects were oriented perpendicular to the coast. We set up markers to aid in delineating a $500 \mathrm{~m}$ strip on each side of the aircraft when it was $100 \mathrm{~m}$ above ground and recorded all caribou within those strips. Most transects were $10 \mathrm{~km}$ or less in length because very few caribou were observed more than $7 \mathrm{~km}$ from the coast (average distance from the coast $=2.9 \mathrm{~km} \pm 2.8 \mathrm{SD}$ ). The survey was conducted on 29 and 30 October 2007 and covered $651 \mathrm{~km}$ of transects, representing an area of $651 \mathrm{~km}^{2}(0.5 \mathrm{~km}$ width on each side of the transect line). The total survey area was $3757 \mathrm{~km}^{2}$ divided into five strata (Fig. 3b) covered at $11 \%$ to $20 \%$ (mean coverage of the study area $=17.3 \%$ ).

During the flights we recorded dead caribou and classified each one as drowned (when caribou had broken through the ice), killed (when seen on the ice or on the land with blood visible) or unknown (when no blood was visible and drowning was rejected). We also recorded any muskoxen, wolves, and other carnivores observed during the survey. For each observation, a waypoint was added onto a GPS, and the airplane flight track was recorded during all reconnaissance and survey flights.

\section{Survey Area Caribou Estimate}

To estimate the total number of caribou within the study area, we used only the individuals observed within the $1 \mathrm{~km}$ wide transect strips. Caribou observed outside the $1 \mathrm{~km}$ wide strip were recorded to inform the distribution.

We calculated the caribou population estimate within each stratum using Jolly's Method 2 for unequal sample sizes (Jolly, 1969 in Norton-Griffiths, 1978). All sexes and ages were pooled, as it was difficult to classify individuals during the survey. Lake areas, being frozen at the time of the survey, were not subtracted from the total area used in density calculations (statistical analysis adapted from Campbell and Setterington, 2001).

The estimate of the Dolphin and Union caribou within our survey area was produced from the sum of the estimates in each stratum. We also created a stratum for islands where caribou had gathered at the edge of the freezing sea ice. This stratum was surveyed by aerial photography (Canon Rebel digital camera, 10 megapixels); all the caribou were counted visually or from the photographs, and the count was added to the survey estimate. The photographs were overlapping, and landmarks were used to avoid double counts or missed individuals. Photographs were imported as maps in OziExplorer (version 5.95.4q), and a waypoint was created for each caribou (J. Nagy, pers. comm. 2006).

\section{Total Caribou Herd Estimate}

Although we were confident that the core of the herd was within our study area, we acknowledged that some caribou might not have reached the study area and therefore were not included in the estimate. In an attempt to account for these caribou and provide a more accurate picture of the 


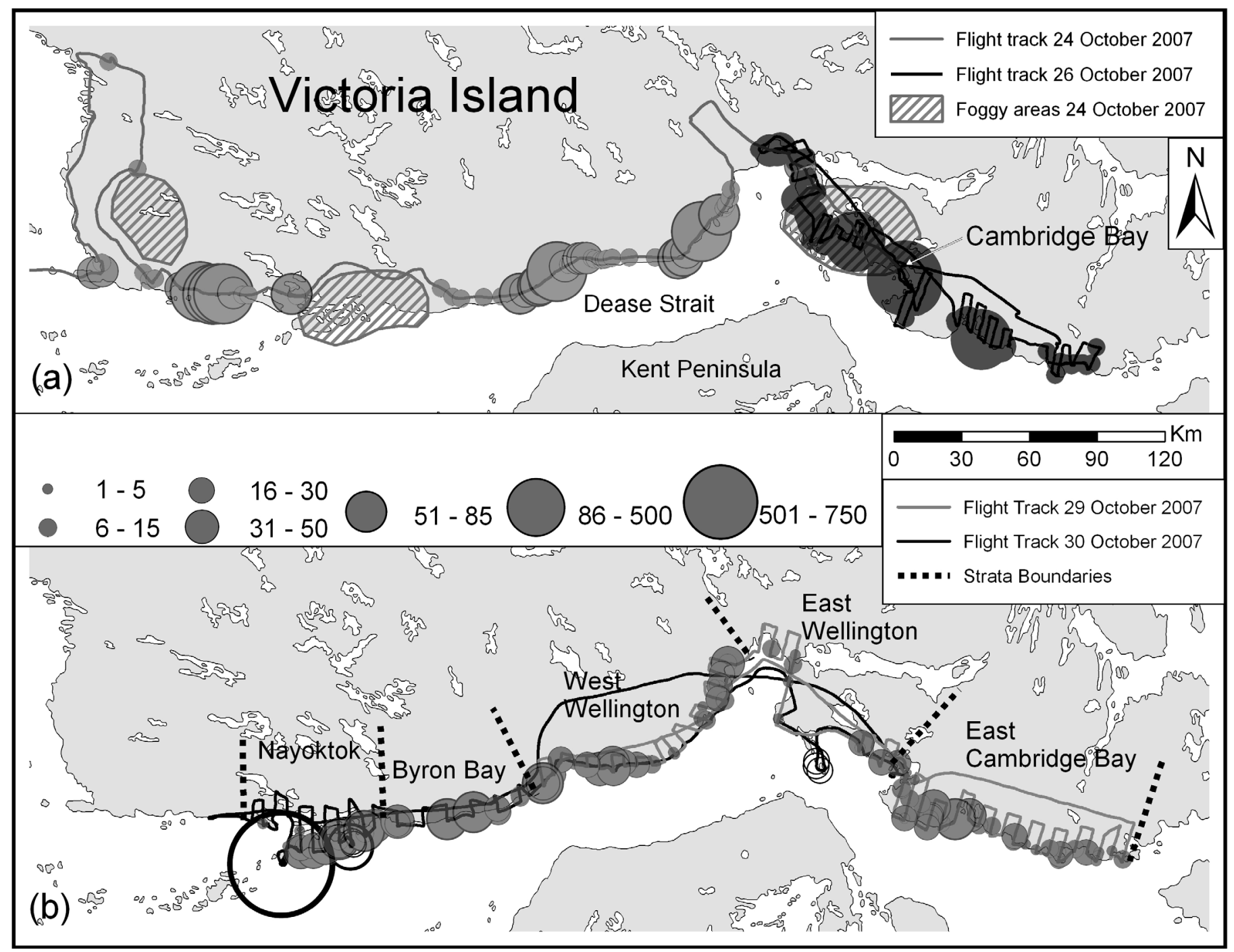

FIG. 3. Dolphin and Union Caribou herd 2007 survey area and caribou observations on the southern coast of Victoria Island, Nunavut. (a) Caribou observed during the aerial reconnaissance survey on 24 and 26 October. (b) Distribution and abundance of caribou observed on transect during the systematic aerial survey on 29 and 30 October. Names of strata and their boundaries (dotted lines) are also shown.

herd status (abundance and trend), we used collar data from previous years (we did not have collared caribou during the 2007 survey) to estimate the proportion of caribou that were outside our study area. This method was based on two assumptions: (1) that caribou behaviour and movement patterns were consistent from year to year (Poole et al., 2010), and (2) that the number of non-collared animals associated with each collared animal is similar both within and outside our study area. To estimate $p_{\text {a }}$ (the probability that a caribou would be within the study area), we used SVIC99-06 satellite collar data sets (one location per day from October 26 to October 30, $\mathrm{n}=34$ caribou $\bullet$ year) for 2000, 2001, and 2002, the three most recent years with sufficient collar data. We discarded data from subsequent years (2003-05) because the number of collared caribou decreased from seven in 2003 to only two in 2004 and 2005, and these were distributed mainly in the eastern portion of the herd range. All spatial data were analyzed using ArcGIS 9.0. Only females were fitted with radio-collars, but because the period considered here followed the rut, we assume that these data are a fair representation of both male and female distribution.

We assigned a probability for each collared caribou to be within our study area during the time of our survey. Poole et al. (2010) showed that the duration of staging along the coast was not influenced by sea ice formation; however, the start of the fall migration to the southern coast of Victoria Island had a weak correlation with new and grey ice formation $\left(\mathrm{r}^{2}=0.07, p=0.044\right.$ and $\mathrm{r}^{2}=0.10, p=0.017$, respectively). During our survey, the ice was not strong enough to allow movements to the mainland; therefore, when examining the 26-30 October data from 2000 to 2002, we included in the study area collar locations of caribou that were on the sea ice or had crossed to the mainland. This choice may have resulted in a slightly conservative population estimate if late ice formation actually delayed the fall staging on the coast. We then used the following formula to calculate the probability for a caribou to be "available" within the study area during the survey $\left(p_{\mathrm{a}}\right)$ : 


$$
p_{\mathrm{a}}=\sum p_{\mathrm{y}} / \mathrm{N}_{\text {years }}
$$

where $p_{\mathrm{y}}=$ the probability of a caribou being in the study area between 26 October and 30 October for a given year (mean $p_{\mathrm{xy}}$ for year $\mathrm{y}$ ), $p_{\mathrm{xy}}=$ the probability for a given caribou (x) to be within the study area between 26 October and 30 October in a given year (y) calculated as the count of a given caribou (x) locations within the study area $/ \mathrm{n}_{\mathrm{xy}}, \mathrm{n}_{\mathrm{xy}}=$ the number of collar locations from 26 October to 30 October of year $\mathrm{y}$ for caribou $\mathrm{x}$, and $\mathrm{N}_{\text {years }}=$ the number of years of data.

We adjusted the Dolphin and Union caribou herd estimate by adapting equations 14 and 15 in Innes et al. (2002), where $\mathrm{N}^{* *}=\mathrm{N}^{*} / p_{\mathrm{a}}, \mathrm{N}^{* *}=$ the corrected estimate, and $\mathrm{N}^{*}=$ the estimate based on caribou within the study area ("available" during the survey). The use of SVIC99-06 satellite collar data from 2000 to 2002 to obtain $p_{\mathrm{a}}$ for our study area leads to the following calculation for the estimate:

$$
\mathrm{N}^{* *}=\left[\left(\mathrm{N}^{*}\right) / p_{\mathrm{a}}\right]
$$

Variance is then $\operatorname{Var}\left(\mathrm{N}^{* *}\right)=\left(\mathrm{N}^{* *}\right)^{2}\left[\mathrm{CV}^{2}\left(\mathrm{~N}^{*}\right)+\mathrm{cv}^{2}\left(p_{\mathrm{a}}\right)\right]$, with $\mathrm{cv}^{2}\left(\mathrm{~N}^{*}\right)=\operatorname{var}\left(\mathrm{N}^{*}\right) /\left(\mathrm{N}^{*}\right)^{2}$ where $\mathrm{CV}$ is the coefficient of variation of $\mathrm{N}^{*}$.

We used the same method to adjust the 1997 survey estimate. Available VHF collar data from the 1997 survey (Nishi and Gunn, 2004) indicated that the probability of caribou being in the study area during the survey was $p_{\text {a } 1997 \mathrm{VHF}} \geq 0.75$ (some collars were not found, which is why $p_{\text {a } 1997 \mathrm{VHF}}$ is a minimum value). Because it was not possible to calculate a variance and $\mathrm{CV}$ for $p_{\mathrm{a}} 1997 \mathrm{VHF}$, and since the proportion of collared caribou within the 1997 study area was similar to $p_{\mathrm{a} 2000-2002}$, we corrected the 1997 estimate in the same way as the 2007 estimate, using $p_{\text {a2000-2002 }}$ and its variance.

We repeated the same process with the 1994 survey (Nishi and Buckland, 2000). The 1994 survey was done in the summer on the western half of Victoria Island, and the proportion of VHF collars within the study area was $p_{\text {a } 1994 \mathrm{VHF}} \geq 0.65$.

For the sake of comparison, we also ran our data through the formula to estimate the caribou population size on the basis of post-calving photographic surveys, as presented by Russell et al. (1996), and the Lincoln-Petersen Index applied to radio-telemetry data (White and Garrott, 1990), using the following formula:

$$
\mathrm{N}=(((\mathrm{M}+1) \cdot(\mathrm{C}+1)) /(\mathrm{R}+1))-1
$$

where $\mathrm{N}=$ estimate of population size, $\mathrm{M}=$ the number of radio-collared animals in the herd, $\mathrm{C}=$ the number of caribou observed in post-calving aggregations containing at least one collared animal, and $\mathrm{R}=$ the number of collared caribou observed in these aggregations.

The variance for the estimate can then be calculated as:

$$
\frac{\operatorname{Var}(\mathrm{N})=(\mathrm{M}+1)(\mathrm{C}+1)(\mathrm{M}-\mathrm{R})(\mathrm{C}-\mathrm{R})}{(\mathrm{R}+1)^{2}(\mathrm{R}+2)}
$$

Because we did not have collar data during the survey, we considered caribou within the study area as one group and calculated $\mathrm{M}$ as the average number of collared animals between 2000 and 2002, C as the estimate within the study area, and $\mathrm{R}$ as $\mathrm{M} \bullet p_{\mathrm{a}}$.

In 2005, a small portion of the herd summering on the northwest part of the island was surveyed in July (Nagy et al., 2006), when the Dolphin and Union caribou herd is spread over most of Victoria Island. These caribou mix with the rest of the herd in the fall, but data from collared caribou suggest that they do not always reach the southern coast of the island at the same time (Poole et al., 2010). Aerial surveys conducted in the area between 1998 and 2005 estimated that the number of these caribou varied between $423 \pm 201(95 \%$ Confidence Interval [CI]) and $1357 \pm 480$ (95\% CI) animals. Because of their relatively small numbers and their delay in reaching the study area, we considered this part of the herd negligible in our calculation and did not include these collar data in our calculation of $p_{\mathrm{a}}$. However, we acknowledge that the unknown portion of these animals that did not reach the survey area should be added to the herd estimate.

\section{Trend Analysis}

To determine trend in caribou abundance in the study area, we compared the 2007 population estimate to the 1997 estimate using equation 5.3 of Thompson et al. (1998):

$$
z=\frac{Y_{1997}-Y_{2007}}{\sqrt{\operatorname{Var}\left(Y_{1997}\right)+\operatorname{Var}\left(Y_{2007}\right)}}
$$

where $\mathrm{Y}=$ the caribou population estimate, $z=$ the $z$ statistic, $Y_{x}=$ the population estimate for year $\mathrm{x}$, and $\operatorname{Var}\left(\mathrm{Y}_{\mathrm{x}}\right)=$ the variance of the population estimate.

The statistics were based on the hypothesis that the population estimate did not change between surveys; therefore, we used the two-tailed probability of the $z$ statistic.

\section{RESULTS}

During the reconnaissance flights on 24 and 26 October 2007 , most of the caribou were either static or moving eastward. During the survey, most of the caribou in the East Cambridge Bay and East Wellington strata were static, the caribou in the West Wellington and Byron Bay strata were mainly moving westward along the coast, and the caribou in the Nayoktok stratum were static or moving eastward. The caribou in the Islands stratum were mainly static.

We observed a total of 12686 caribou during the survey itself (Table 1), including 2669 seen on transect and 4362 counted on small islands. From the analysis in the five strata and the addition of total counts on small islands, 
TABLE 1. Estimated population of Dolphin and Union caribou within the aerial survey area along the southern coast of Victoria Island, Nunavut, on 29 and 30 October 2007.

\begin{tabular}{|c|c|c|c|c|c|c|c|c|c|}
\hline Stratum & Date & $\begin{array}{c}\text { Stratum } \\
\text { area }\left(\mathrm{km}^{2}\right)\end{array}$ & $\begin{array}{l}\text { Number of } \\
\text { transects }\end{array}$ & $\begin{array}{l}\text { Study area } \\
\text { coverage }\end{array}$ & $\begin{array}{c}\text { Caribou } \\
\text { on transect }\end{array}$ & $\begin{array}{l}\text { Total caribou observed } \\
\text { (on and off transect) }\end{array}$ & $\begin{array}{l}\text { Estimate within } \\
\text { the study area }\end{array}$ & $\begin{array}{l}\text { Standard } \\
\text { error }\end{array}$ & $\begin{array}{l}\text { Coefficient } \\
\text { of variation }\end{array}$ \\
\hline East Cambridge Bay & 29 October & 1388 & 24 & $20 \%$ & 672 & 2517 & 3360 & 703 & 0.21 \\
\hline East Wellington & 29 October & 528 & 7 & $12 \%$ & 529 & 1199 & 4348 & 1577 & 0.36 \\
\hline West Wellington & 29 October & 786 & 20 & $17 \%$ & 559 & 1372 & 3353 & 674 & 0.20 \\
\hline Byron Bay & 30 October & 349 & 6 & $11 \%$ & 412 & 1906 & 3844 & 1142 & 0.30 \\
\hline Nayoktok & 30 October & 706 & 11 & $20 \%$ & 497 & 1330 & 2486 & 865 & 0.35 \\
\hline Islands & 30 October & NA & NA & Count & NA & 4362 & 4362 & NA & NA \\
\hline Total & & & & & & 12686 & 21753 & 2343 & 0.13 \\
\hline
\end{tabular}

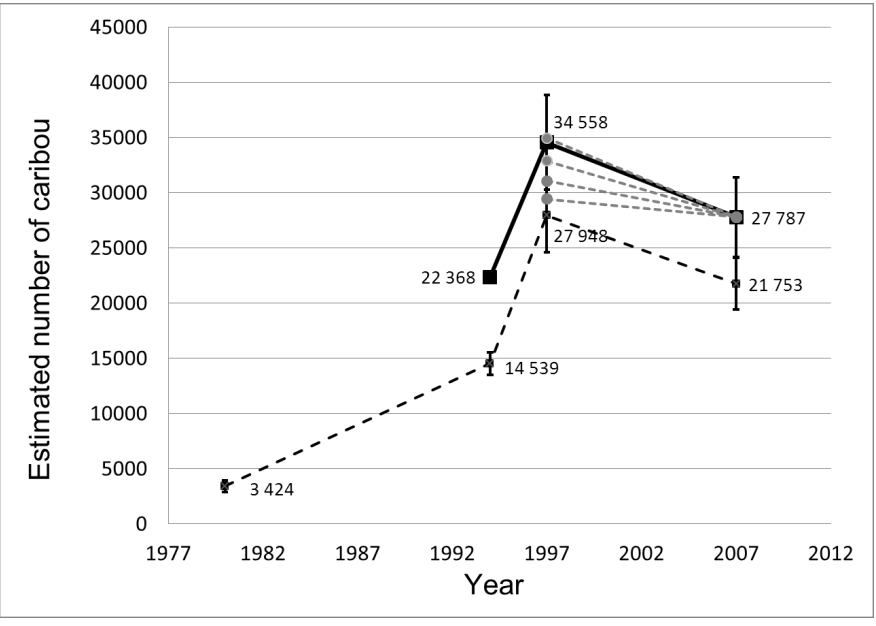

FIG. 4. Variation of the Dolphin and Union caribou herd estimates from 1980 to 2007 (standard error is shown). The dark grey dashed line shows the estimate in the study area, and the black solid line shows the extrapolated estimate for the whole herd. The grey dots represent the 1997 herd estimate calculated with values of $p_{\mathrm{a}}$ ranging from 0.80 to 0.95 (see text for calculation method) and the grey dotted lines, the associated trend. Note that the 1980 (Jakimchuk and Carruthers, 1980) and 1994 (Nishi and Buckland, 2000) surveys were conducted at different times of the year and in different areas.

we estimated $21753 \pm 2343 \mathrm{SE}$ animals from the Dolphin and Union caribou herd within the study area (Table 1). While graphic results (Fig. 4) suggest a lower abundance compared to the 1997 survey estimate of $27948 \pm 3367 \mathrm{SE}$ (Nishi and Gunn, 2004) and are consistent with information gathered through local hunters and conservation officers, there was not a statistical difference between the two survey area point estimates of 1997 and $2007(z=1.51, p=$ $0.13)$.

Using the correction based on collared caribou data $\left(p_{\mathrm{a} 2000-2002}=0.81\right)$, we obtained a 2007 estimate for the whole Dolphin and Union caribou herd of $27787 \pm 3613$ SE individuals (Table 2). The $95 \%$ confidence interval was \pm 7537 and was calculated with a degree of freedom estimated at 20 (based on the formula in Nagy et al., 2006). The Lincoln-Petersen Index method provided a similar result, with a 2007 herd estimate of $26417 \pm 3244$ caribou.

The corrected estimate for the Dolphin and Union caribou herd in October 1997 (using $p_{\text {a2000-2002 }}=0.81$ ) was at or below $34558 \pm 4283 \mathrm{SE}$. The $95 \%$ confidence interval was \pm 6801 . The difference between the two corrected estimates (1997 and 2007) was not significant $(z=1.21, p=0.23)$.
However, because collared caribou that were not confirmed within the study area in 1997 were not located outside the study area, we also graphed trends between point estimates based on a series of $p_{\text {a }}$ ranging from 0.80 to 0.95 in increments of 0.05 (Fig. 4). We did not calculate the variance for the point estimates, as we had no data to estimate the variance of $p_{\mathrm{a}}$.

The 1994 corrected estimate for the Dolphin and Union herd $\left(p_{\text {a } 1994 \mathrm{VHF}} \geq 0.65\right)$ was then 22368 or fewer caribou (Fig. 4). We did not calculate the variance for this corrected estimate as we had no data to estimate the variance of $p_{\text {a } 1994 \mathrm{VHF}}$.

During the flights, we observed three drowned caribou, 15 kill sites, and two caribou dead from unknown causes. We observed 3752 muskoxen distributed on most of the areas flown and two wolf packs ( 2 and 9 individuals).

\section{DISCUSSION}

The late formation of sea ice and rapid changes in weather prevented coverage of all the areas originally planned in the western and eastern parts of the study area. However, the reconnaissance flight and the 1997 survey results (Nishi and Gunn, 2004) suggested that high caribou densities were included in our survey area. Using caribou satellite collar data from previous years, we produced a corrected estimate for the Dolphin and Union caribou herd on Victoria Island of $27787 \pm 3613 \mathrm{SE}$ animals that accounts for animals outside our study area. This correction, while increasing the estimate for the herd, did not affect the main conclusion regarding the trend of the herd. Our results show that from 1997 to 2007, the Dolphin and Union caribou herd at best remained stable, in contrast to the five- to tenfold increase documented between 1980 and 1997 (Jakimchuk and Carruthers, 1980; Nishi and Buckland, 2000; Nishi and Gunn, 2004). Our findings are consistent with observations by local hunters, who have reported that the herd increase had slowed or stopped, and with trends observed in the northwestern part of Victoria Island during July aerial surveys (increase from 1998 to 2001 and then no significant difference between the 2001 and 2005 estimates; Nagy et al., 2006).

The Lincoln-Petersen Index method and the method developed by Innes et al. (2002) provided similar point 
TABLE 2. Dolphin and Union caribou survey results from 1994, 1997, and 2007 and 2007 herd estimate.

\begin{tabular}{|c|c|c|c|c|}
\hline Dates & 5-17 June 1994 & $17-22$ October 2005 & $26-30$ October 2007 & \\
\hline Estimate & 14539 & 27948 & 21753 & 27787 \\
\hline Standard error & 1015 & 3367 & 2343 & 3613 \\
\hline Coefficient of variation $\mathrm{CV}(\mathrm{N})$ & 0.07 & 0.12 & 0.13 & 0.13 \\
\hline Probability of caribou in study area $\left(p_{z}\right)$ & $\geq 0.65$ & $\geq 0.75$ & 0.81 & NA \\
\hline $\mathrm{CV}\left(p_{\mathrm{a}}\right)$ & NA & NA & 0.012 & NA \\
\hline
\end{tabular}

${ }^{1}$ Nishi and Buckland (2000).

${ }^{2}$ Nishi and Gunn (2004).

3 This study.

estimates and variance. However, we argue that the Innes et al. (2002) method is more appropriate in our case as it is assessing the availability of the animals within the study area using data collected at a different time than the survey. Innes et al. (2002) estimated the probability of marine mammals to be within a strip of water below the surface (where they can be observed from an aircraft) on the basis of multi-year radio-tracking data on frequency and depth of dives, and we estimated the probability that caribou would be within a strip along the coast (where they could be observed during the aerial survey) using multi-year radiotracking data on the timing and location of caribou use of our study area.

To increase the accuracy of our method, we recommend that satellite/GPS collars be deployed on this herd and monitored during future surveys to better inform the timing of the survey and the calculation of $p_{\mathrm{a}}$ and to verify the underlying assumptions related to this method. Also, the trend toward later sea ice formation in the study area has made it extremely challenging to operate small aircraft safely in October-November, and the survey window is very short. We therefore recommend exploring alternative methods for surveying this herd. For example, if sufficient satellite/GPS collars are active, a variation of the post-calving survey method (with aerial photographs) could be used during the fall staging or spring pre-migration aggregation as an alternative to the October-November surveys. A survey of the calving ground is probably not possible for this herd, as its calving strategy is mainly individualist (Nagy et al., 2011): the females do not aggregate within one or more finite calving grounds, but rather spread over most of Victoria Island during the calving and post-calving periods.

Accurate long-term monitoring of this caribou herd is crucial to its management and conservation. We can only speculate about the factors responsible for the population dynamics observed for $1980-2007$, but the six described below seem plausible. First, both the caribou (Nishi and Gunn, 2004) and muskox (Patterson and Gunn, 1999) populations on the Island increased during the 1980s and 1990s. Second, the reduction in winter food supply on Victoria Island when the Dolphin and Union caribou herd resumed its migration to the mainland may have kept the already low carnivore populations on the island from increasing during the first decade. Third, carnivore abundance and distribution in the landscape may have influenced caribou mortality and recruitment and ultimately population dynamics. Fourth, sea ice conditions related to delayed ice formation may have increased caribou mortality during the fall migration (Poole et al., 2010; Allen Niptanatiak, pers. comm. 2010), affecting the population growth rate. Fifth, vegetation status and parasite prevalence may have contributed to intra- and inter-specific density-dependent regulatory mechanisms (Hughes, 2006). Sixth, the cumulative impacts of mineral exploration and mining activities, mainly on the herd's winter ground, have been poorly monitored and remain a source of uncertainty and concerns. Each of these factors may have influenced the Dolphin and Union herd population dynamics independently or cumulatively; they signify the importance of continued and improved monitoring of the population, including telemetry of individuals.

With the limited number of radio collars currently deployed on the herd and the lack of formal and accurate harvest monitoring, it is not possible to model harvest and other forms of mortality. The estimated harvest from the herd likely increased between 2000 and 2007 (Dumond et al., 2007), and especially from 2006 to 2008, as a result of the decreased availability of other barren-ground caribou herds (Dumond et al., 2007). Subsequently, the Kugluktuk Hunters and Trappers Association implemented several initiatives (education and communication to reduce wastage and improve harvest practices; hunting of alternative species) that reduced the caribou harvest and particularly the harvest of the Dolphin and Union caribou herd. Also in fall 2007 and 2008, several hunters reported that a number of Dolphin and Union caribou were very skinny and had signs (ice on the fur and cuts on the legs) that they had fallen through the ice during the fall migration. The relatively low number of dead caribou recorded during the 2007 survey could be the result of ice being formed only along the coast so that many caribou had not yet ventured onto the forming sea ice. Mortality due to ice condition is likely higher during the actual crossing to the mainland. In spring 2010, a few dozen caribou carcasses were found frozen in the ice and on small islands near the mainland, obviously having died in the water or shortly after getting out of the water (Allen Niptanatiak and Dustin Fredlund, pers. comm. 2010; 
Mathieu Dumond, pers. obs. 2010). The fall migration is the period of highest natural mortality (Poole et al., 2010). The quantitative assessment of mortality related to ice conditions would require monitoring of both male and female movements and the resources to confirm the cause of death. While hunters' observations are valuable, this mortality occurs when the sea ice is too thin to allow all-terrain vehicle travel and environmental conditions are challenging for aircraft. Maritime traffic, if affecting ice formation, may add to already existing stresses on this herd during spring and fall migration (Dumond et al., 2013). Co-management partners and stakeholders have initiated discussions to address some of the concerns related to the Dolphin and Union caribou herd, including its monitoring and the foundation of a management plan.

\section{ACKNOWLEDGEMENTS}

The authors would like to thank Perry Linton, pilot of the Helio-Courier, for his enthusiasm, flexibility, and amazing piloting skills. He made the survey a success despite difficult weather conditions. Thanks to Shane Sather and Rob Harmer, Conservation Officers in Cambridge Bay, for their assistance on the ground and during the field work as observers. Thanks to Damian Matumiak and George Aitaok for their participation as observers. Thanks to Kathy Aitaok, Ekaluktutiak HTO manager, for her help in coordinating observers for the survey. Thank you to Anne Gunn, John Boulanger, and Nicolas Lecomte for their comments on previous drafts of this manuscript. Thank you to Marco Festa-Bianchet and two anonymous reviewers for their constructive comments on the manuscript. Funding was provided by the Department of Environment (Government of Nunavut) and the Nunavut Wildlife Management Board.

\section{REFERENCES}

Campbell, M., and Setterington, M. 2001. The re-evaluation of Kivalliq and Northeast Kitikmeot muskox (Ovibos moschatus) populations, management zones and quotas. Technical Report Series 2001, No. 1-02. Arviat: Nunavut Wildlife Division, Department of Environment. 97 p.

Canada Gazette. 2011. Order amending Schedule 1 to the Species at Risk Act, SOR/2011-5 to 30 and SI/2011-9 to 14. http://www. sararegistry.gc.ca/virtual_sara/files/orders/g2-14504ii_e.pdf.

COSEWIC (Committee on the Status of Endangered Wildlife in Canada). 2004. COSEWIC assessment and update status report on the Peary caribou Rangifer tarandus pearyi and the barren-ground caribou Rangifer tarandus groenlandicus Dolphin and Union population in Canada. Ottawa: COSEWIC. http://publications.gc.ca/collections/Collection/CW69-14-1912004E.pdf.

Dumond, M., Algona, B., Bolt, C., Bolt, M., Ivarluk, J., Klengenberg, S., Taktogon, P., et al. 2007. Western Kitikmeot Caribou Workshop. Final Wildlife Report 19. Kugluktuk: Department of Environment, Government of Nunavut.
Dumond, M., Sather, S., and Harmer, R. 2013. Observation of Arctic island barren-ground caribou (Rangifer tarandus groenlandicus) migratory movement delay due to human induced sea-ice breaking. Rangifer 33, Special Issue 21:115-121.

Environment Canada. 2013. Canadian climate normals or averages 1971-2000. http://www.climate.weatheroffice.gc.ca/ climate_normals/index_e.html.

Federal Register. 2011. Endangered and threatened wildlife and plants: 90-day finding on a petition to list the Peary caribou and Dolphin and Union population of the barren-ground caribou as endangered or threatened. Federal Register 76(65):18701-18706.

GNWT-RWED (Government of the Northwest Territories, Department of Resources, Wildlife, and Economic Development). 1998. Southern Victoria Island (Dolphin and Union) caribou management planning: Summary of user community concerns and action items. Kugluktuk: GNWTRWED.

Gould, W.A., Edlund, S., Zoltai, S., Raynolds, M., Walker, D.A., and Maier, H. 2002. Canadian Arctic vegetation mapping. International Journal of Remote Sensing 23(21):4597-4609.

Gunn, A. 1990. The decline and recovery of caribou and muskoxen on Victoria Island. In: Harington, C.R., ed. Canada's missing dimension: Science and history in the Canadian Arctic Islands, Vol. II. Ottawa: Canadian Museum of Nature. 590-607.

Gunn, A., and Fournier, B. 2000. Caribou herd delimitation and seasonal movements based on satellite telemetry on Victoria Island 1987-89. File Report 125. Yellowknife: Department of Resources, Wildlife, and Economic Development, GNWT.

Gunn, A., and Nishi, J. 1998. Review of information for Dolphin and Union caribou herd, Victoria Island. In: Gunn, A., Seal, U.S., and Miller, P.S., eds. Population and Habitat Viability Assessment Workshop for the Peary caribou (Rangifer tarandus pearyi): Briefing book. Apple Valley, Minnesota: Conservation Breeding Specialist Group (SSC/UCN). 1-22.

Gunn, A., and Patterson, B. 2012. Distribution and abundance of muskoxen on southeastern Victoria Island, Nunavut 1988 - 1999. Manuscript Report 222. Yellowknife: Department of Environment and Natural Resources, GNWT. http://www. enr.gov.nt.ca/_live/documents/content/222_manuscript.pdf.

Hughes, J.R. 2006. The influence of forage and parasites on the migration of the Dolphin-Union caribou herd. PhD dissertation, University of Aberdeen, Aberdeen. $150 \mathrm{p}$.

Innes, S., Heide-Jørgensen, M.P., Laake, J.L, Laidre, K.L., Cleator, H.J., Richard, P., and Stewart, R.E.A. 2002. Survey of belugas and narwhals in the Canadian High Arctic in 1996. NAMMCO Scientific Publications 4:169-190.

Jakimchuk, R.D., and Carruthers, D.R. 1980. Caribou and muskoxen on Victoria Island, N.W.T. Report prepared for Polar Gas Project by R.D. Jakimchuk Management Associates, Sidney, British Columbia. 93 p.

Jolly, G.M. 1969. Sampling methods for aerial census of wildlife populations. East African Agricultural Forestry Journal 34:46-49.

Nagy, J., Gunn, A., and Wright, W.H. 2009. Population estimates for Peary caribou (Minto Inlet herd), Dolphin and Union 
caribou, and muskox on northwest Victoria Island, NT, July 2005. Manuscript Report 203. Yellowknife: Department of Environment and Natural Resources, GNWT. http://www.enr. gov.nt.ca/_live/documents/content/203_manuscript.pdf.

Nagy, J.A., Johnson, D.L., Larter, N.C., Campbell, M.W., Derocher, A.E., Kelly, A., Dumond, M., Allaire, D., and Croft, B. 2011. Subpopulation structure of caribou (Rangifer tarandus L.) in Arctic and sub-Arctic Canada. Ecological Applications 21(6):2334-2348.

Nishi, J.S., and Buckland, L. 2000. An aerial survey of caribou on western Victoria Island (5-17 June 1994). File Report 128. Kugluktuk and Yellowknife: Department of Resources, Wildlife and Economic Development, GNWT.

Nishi, J.S., and Gunn, A. 2004. An estimate of herd size for the migratory Dolphin and Union caribou herd during the rut (17-22 October 1997). File Report 131. Kugluktuk and Yellowknife: Department of Resources, Wildlife and Economic Development, GNWT.
Norton-Griffiths, M. 1978. Counting animals: Serengeti Ecological Monitoring Programme. Handbook No. 1. Nairobi, Kenya: Afropress Ltd. 139 p.

Poole, K., Gunn, A., Patterson, B.R., and Dumond, M. 2010. Sea ice and migration of the Dolphin and Union caribou herd in the Canadian Arctic: An uncertain future. Arctic 63(4):414-428.

Russell, H.J., Couturier, S., Sopuck, L.G., and Ovaska, K. 1996. Post-calving photo-census of the Rivière George caribou herd in July 1993. Rangifer Special Issue 9:319-330.

Thompson, W.L., White, G.C., and Gowan, C. 1998. Monitoring vertebrate populations. San Diego: Academic Press Inc. 365 p.

White, G.C., and Garrott, R.A. 1990. Analysis of wildlife radiotracking data. San Diego: Academic Press.

Zittlau, K.A. 2004. Population genetic analyses of North American caribou (Rangifer tarandus). PhD dissertation, Department of Biological Sciences, University of Alberta, Edmonton, Alberta. 